UDK: $811.521 .161 ' 373$

DOI: $10.33669 / \mathrm{KJ} 2021-32-02$

primljeno / received: 25.2. 2021.

prihvaćeno / accepted: 12. 12.2021.
Izvorni naučni rad

\section{Edina Solak}

Odsjek za turski jezik i književnost

Filozofskoga fakulteta

Univerziteta u Zenici

Travnička cesta 8, 72000 Zenica,

Bosna i Hercegovina

edina262@gmail.com

\section{Mirza Bašić}

Odsjek za turski jezik i književnost

Filozofskoga fakulteta

Univerziteta u Zenici

Travnička cesta 8,72000 Zenica

Bosna i Hercegovina

basicmirza99@gmail.com

\title{
Pragmatička uloga različitih tipova šutnje u romanu Kafamda bir tuhaflik autora Orhana Pamuka
}

Sažetak: U određenim konverzacijskim situacijama šutnja ne predstavlja samo odsustvo govora već se koristi kao komunikacijsko sredstvo kojim se prenose različita značenja. Cilj rada jeste analizirati pragmatičku ulogu šutnje u romanu Kafamda Bir Tuhaflık autora Orhana Pamuka. Primjeri šutnje evidentirani u originalnome tekstu romana Kafamda Bir Tuhaflk kontrastivnom se analizom uspoređuju s tipovima šutnje koji su predstavljeni u prijevodu na bosanski jezik. Na taj se način pokušava utvrditi da li određeni tipovi šutnje imaju identičnu pragmatičku vrijednost u turskome i bosanskome jeziku. U analizi se uspoređuju i sintaksičke konstrukcije kojima se označavaju različiti tipovi šutnje u originalnome tekstu romana i u prijevodu na bosanski jezik. Turski jezik predstavlja ishodišni jezik u ovoj analizi. Dakle, sintaksičke konstrukcije kojima se izražavaju različiti primjeri šutnje u originalnome tekstu romana uspoređuju se s prijevodnim ekvivalentima u bosanskome jeziku. Analiza konkretnih kontekstualnih primjera pokazuje da uspješnost međuljudske komunikacije u velikoj mjeri zavisi i od pravilnoga spoznavanja i razumijevanja različitih tipova šutnje. Rezultati dobijeni u analizi daju doprinos boljem spoznavanju i razumijevanju različitih tipova šutnje u različitim konverzacijskim situacijama, ali mogu poslužiti i 
kao dobar temelj i dobro polazište za daljnja istraživanja u vezi s različitim tipovima šutnje.

Ključne riječi: šutnja, pragmatička uloga, sintaksičke konstrukcije, turski jezik, bosanski jezik

\section{Uvod}

Analiza različitih tipova šutnje u različitim kontekstualnim situacijama jeste pitanje kojim se bave pragmatičke discipline analiza konverzacije i analiza diskursa. Naime, šutnja ne predstavlja samo odsustvo govora, prvenstveno zato što se različiti tipovi šutnje mogu upotrebljavati kao komunikativni resursi kojima se prenose različita značenja u različitim kontekstualnim situacijama (v. Levinson 1983: 299; Stević 1997: 41; Katnić-Bakaršić 2013: 170-172).

Uspješnost svakodnevne međuljudske konverzacije zasniva se na činjenici da sudionici konverzacije govore naizmjenično bez preklapanja i većih pauzi, odnosno zastoja. U svakodnevnoj međuljudskoj konverzaciji realiziraju se kratke pauze između turnusa govornika, kojima se, zapravo, daje signal da drugi učesnik konverzacije preuzme riječ. Pored toga, takvim se kratkim pauzama između turnusa govornika može ukazivati i na činjenicu da trenutni govornik oklijeva jer se pokušava sjetiti adekvatnoga izraza kojim bi mogao iskazati svoju misao. Međutim, kada vremenski tok kratkih pauzi traje duže od uobičajenoga, one prelaze u šutnju, za koju je već navedeno da predstavlja komunikativni resurs kojim se prenose različita značenja u različitim kontekstualnim situacijama (v. Bulić 2018: 157-158; Bakšić - Bulić 2019: 140). U ovome se radu analizira pragmatička vrijednost različitih tipova šutnje koji su zabilježeni u tekstu romana Kafamda Bir Tuhaflık turskoga nobelovca Orhana Pamuka. Kontrastivnom se analizom pokušava utvrditi da li određeni primjeri šutnje imaju identičnu pragmatičku ulogu u turskome i bosanskome jeziku. Uspoređuju se i sintaksičke konstrukcije kojima se izražavaju različiti tipovi šutnje u originalnome tekstu romana i u prijevodu na bosanski jezik. Kao temeljni izvor građe koriste se primjeri iz prijevoda koji potpisuju Sabina Bakšić i Alena Ćatović. Ovaj se prijevod koristi kao temeljni izvor građe jer ga potpisuju prevoditeljice 
koje se bave pragmatikom i koje posjeduju sve potrebne kompetencije $\mathrm{u}$ vezi s pragmatičkom ulogom šutnje u svakodnevnoj međuljudskoj konverzaciji. Stoga je navedeni prijevod dobar temelj za jednu ovakvu analizu. U teorijskome smislu metodologija analize zasniva se na temeljnim postulatima u vezi s pragmatičkim vrijednostima šutnje koje je Halid Bulić detaljno, deskriptivno i na temelju konkretnih kontekstualnih primjera predstavio u studiji Pragmatički aspekti romana Ponornica Skendera Kulenovića. U poglavlju studije naslovljenome Pragmatička vrijednost šutnje analizira se pragmatička funkcija šutnje u konverzacijskim situacijama zabilježenim u romanu Ponornica. Uočeni primjeri šutnje klasificiraju se na temelju pragmatičke vrijednosti koju nose, a u analizi se evidentira 17 tipova šutnje (v. Bulić 2018: 157-171). Bulićeva analiza može poslužiti "kao model po kome se može istraživati šutnja u drugim korpusima i kontekstima te kao studija slučaja doprinijeti ukupnosti znanja o šutnji u konverzaciji i literarnim djelima” (Bulić 2018: 171). Kao što je već navedeno, u našem se radu Bulićeva studija koristi kao model prema kojem se analizira pragmatička funkcija šutnje u konverzacijskim situacijama zabilježenim u romanu Kafamda Bir Tuhaflık i prijevodu romana na bosanski jezik. I nazivi tipova šutnje preuzimaju se iz Bulićeve studije, ali je važno naglasiti činjenicu da su nazivi pojedinih tipova šutnje naši. To su tipovi šutnje koji se realiziraju u konverzacijskim situacijama koje nisu oprimjerene u romanu Ponornica, odnosno tipovi šutnje koji nisu analizirani u studiji koja predstavlja model na kojem se zasniva naša analiza.

Svi pojmovi koji se navode u ovome radu, a koji imaju rodni značaj i rodno obilježje, obuhvataju na jednak način muški i ženski rod bez obzira na to da li se navode u muškome ili ženskome rodu.

\section{Šutnja nesnalaženja}

U tekstu romana Kafamda Bir Tuhaflık evidentira se šutnja kojom se označava nesnalaženje likova u situaciji u kojoj se zadese. Zapravo, bilježe se primjeri šutnje koja se realizira jer likovi ne znaju šta bi mogli i trebali reći u situaciji u kojoj su se zadesili. Takvu šutnju Halid Bulić naziva šutnjom nesnalaženja (v. Bulić 2018: 159). 
(1) “Ağzını bıçak açmıyor," diye takıldı Süleyman Mevlut’a. (KBT: 19) / "Šutiš", obratio se Sulejman Mevludu. (ČMMG: 22)

(2) Sepetler, denkler, bavullar ve yorgun bir kalabalıkla tıkış tıkış dolu küçük bir bekleme odasında bir bankın ucunda otururlarken ağızlarını açıp birbirlerine tek kelime söylemediler. (KBT: 20) / Sjedili su na rubu klupe u čekaonici prepunoj korpi, paketa, kofera i umorne gomile ljudi i nisu progovarali ni riječi. (ČMMG: 24)

(3) Yillar süren bir evlilikten sonra aralarında konuşacak hiçbir şey kalmamış karı kocalar gibi hiç konuşmadan vagonun penceresinden baktılar. (KBT: 22) / Gledali su kroz prozor vagona poput sredovječnog bračnog para koji više nema o čemu razgovarati. (ČMMG: 26)

(4) Mevlut'un mutfağa girdiği fark edilince içerideki masada bir sessizlik oldu. (KBT: 31) / Kad su primijetili da je Mevlud ušao u kuhinju, za stolom je zavladao muk. (ČMMG: 36 )

(5) O bir şey diyemeden, desteden çektiğim zarfları açıp açıp içinden çıkardığım kâğıtları gelişigüzel okumaya başladım. (KBT: 270) / Počela sam nasumice čitati papire koje sam izvadila iz svežnja koverti a da ona nije stigla ništa reći. (ČMMG: 320)

(6) Birkaç kere de Rayiha'dan sonra dükkânda kaldım ama Mevlut bana sırtını döndü. Arada bir aynaya bakıyordu yalnızca. Ben de bizim aynaya bakar, Mevlut ile hiç konuşmazdım. (KBT: 314) / Nekoliko puta sam ostala u dućanu nakon Rajihe, ali mi je Mevlud okrenuo leđa. Svaki čas bi gledao u ogledalo. I ja bih gledala u naše ogledalo i ne bih uopće razgovarala s Mevludom. (ČMMG: 373)

(7) Bir paket Samsun çıkardı. Yeni barıştığı babasına da bir tane verdi ve sonra kendi de bir tane yakıp dumanını puf diye küçük odanın ortasına üfledi. O zaman hepimiz sustuk. (KBT: 362) / Izvadila je jedan paket cigareta Samsun. Dala je jednu cigaretu i svom ocu s kojim se tek bila pomirila a zatim je i sama zapalila, i otpuhnula dim na sredinu male sobe. Tada smo svi ušutjeli. (ČMMG: 431)

(8) "Ama bu makinayla, el değmeden yapılmış," dedi gözlüklü çocukların büyük olanı. "Sen senin bozanı evde kendi elinle mi yapıyorsun?" Mevlut cevap vermedi. (KBT: 416) / 
"Ali to je napravljeno fabrički bez dodira ruku", pojasnio je stariji dječak s naočalama. "Praviš li ti svoju bozu rukama kod kuće?"

Mevlud nije odgovorio. (ČMMG: 498)

(9) $\mathrm{Bu}$, mektuplar konusunda bir iğneleme miydi? Öyleyse, yedi yıllık evlilikleri boyunca Samiha’nın mektuplar konusunu kırgınlıkla hatırlatmasına ilk defa tanık oluyordu Mevlut. Yağmuru dinleyerek sustular. (KBT: 445) / Da li je to bio sarkazam koji se odnosio na ona pisma? Ako jeste, Mevlud je prvi put za sedam godina braka doživio da ga Samiha uvrijeđeno podsjeća na to. Zašutjeli su osluškujući kišu. (ČMMG: 534)

(10) "Yok, bu akşamı demiyorum. Buraları bırakıp Çukurcuma’ya taşınacakmışsınız." Mevlut cevap vermeyince, "Bizi bırakıp bir yere gidemezsin sen," dedi Korkut. (KBT: 463) / "Ne, ne mislim na večeras. Čujem da idete odavde i da ćete se preseliti na Čukurdžumu." Kako mu Mevlud nije ništa odgovorio, Korkut mu se opet obratio: "Ne možeš nas ostaviti i otići." (ČMMG: 555)

U primjerima (1), (2) i (3) šutnjom se označava nesnalaženje Mevluda i Rajihe u situaciji kada oni bježe nakon što je Mevlud "ukrao" Rajihu, i to prema dobro pripremljenom planu i uz veliku pomoć rođaka Sulejmana. U takvoj situaciji Mevlud i Rajiha ne snalaze se najbolje jer ne znaju o čemu bi mogli i trebali razgovarati. Stoga veći dio njihovoga puta, odnosno bježanja, prolazi u šutnji koja je, zapravo, rezultat njihovoga nesnalaženja. U primjeru (4) šutnjom se označava nesnalaženje veselih, opuštenih i "pripitih" likova u situaciji kada im prodavač boze uđe u kuhinju prekinuvši njihov razgovor ispunjen šalom i duhovitošću. U primjerima (5) i (9) šutnja je rezultat nesnalaženja likova u situaciji kada se spomenu ljubavna pisma za koja ni Mevlud nije siguran da li ih je pisao svojoj suprugi Rajihi ili pak njenoj mlađoj sestri Samihi. Kad god bi se spomenula ljubavna pisma, nastupila bi šutnja kojom se označava nesnalaženje likova u datoj situaciji. U primjeru (6) šutnja se koristi kao komunikativni resurs kojim se izražava nesnalaženje Mevluda i Samihe u situaciji kada ostanu sami u radnji. Naime, očito je da Mevlud i Samiha gaje određene simpatije jedno prema drugome. Međutim, životne okolnosti i sociokulturna stvarnost u kojoj egzistiraju doprinijeli su tome da se Mevlud oženi Samihinom starijom sestrom Rajihom te da 
se Samiha uda za Mevludovoga najboljeg prijatelja. Stoga se njih dvoje ne snalaze najbolje kada ostanu sami jer ne znaju kako bi se trebali ponašati jedno prema drugome te o čemu bi mogli ili trebali razgovarati. U primjeru (7) šutnjom se izražava nesnalaženje likova u situaciji kada ženska osoba po koju su došli prosci zapali cigaretu. Takvo slobodno ponašanje žene po koju su došli prosci nije u skladu s temeljnih postulatima turskoga tradicionalnog društva, zbog čega dolazi do nesnalaženja likova u situaciji u kojoj su se zadesili. U primjeru (8) šutnjom se iskazuje nesnalaženje tradicionalnoga prodavača boze u situaciji kada mušterije upućuju komplimente modernome industrijskom proizvođenju boze kritizirajući tradicionalni način pravljenja boze. Dakle, u primjerima (7) i (8) realizira se šutnja prouzrokovana nesnalaženjem tradicionalnoga koncepta u situaciji kada ga narušavaju postulati savremenoga i modernoga koncepta. U primjeru (10) šutnja označava nesnalaženje Mevluda u situaciji kada se otkrije Samihin i njegov plan u vezi sa selidbom.

U primjeru (1) uočava se da se u originalnome tekstu šutnja nesnalaženja izražava frazemom ă̆zın bıçak açmamak, dok se u prijevodu koristi potvrdan oblik glagola šutjeti. U rječnicima se navodi da frazem ağzını bıçak açmamak ima značenje ne moći progovoriti zbog tuge ili neugodnosti (v. Aksoy 1989: 544; Đinđić - Teodosijević - Tanasković 1997: 18; Đinđić 2014: 59). U bosanskome jeziku značenjski je blizak frazem pojesti maca jezik nekome, ali se ovaj frazem najčešće upotrebljava u situacijama "kad očekujemo da tko progovori ili objasni što, pri čemu čekanje iritira” (Kovačević 2012: 224). Dakle, bosanski frazem pojesti maca jezik nekome najčešće se povezuje s dugotrajnom šutnjom koja postaje neprijatna, a on se ne koristi u prijevodu jer bi se njegovom upotrebom aktivirala drugačija pragmatička vrijednost šutnje u odnosu na originalni tekst. U primjerima (2), (4), (6), (7), (8) i (9) primjećuje se da se šutnja nesnalaženja i u originalnome tekstu i u prijevodu iskazuje potvrdnim oblikom glagola susmak (šutjeti / ušutjeti; zašutjeti) [v. (7) i (9))] i sessizlik olmak (nastupati / nastupiti tišina; zavladati tišina; zavladati muk) [v. (4)], odnosno odričnim oblikom glagola söylemek (govoriti; reći) [v. (2)], konuşmak (pričati / ispričati; govoriti / izgovoriti) [v. (6)] i cevap vermek (odgovarati / odgovoriti) [v. (8)]. U primjerima 
(3) i (5) šutnja nesnalaženja ispoljava se adverbijalnim skupinama u kojima funkciju upravnoga člana ima konverb na - $m A d A n$, koji se dodaje na korijen glagola konuşmak (pričati / ispričati; govoriti / izgovoriti) [v. (3)], odnosno demek (govoriti; reći) [v. (5)], i kojim se označavaju način i okolnosti vršenja radnje koja se izražava korelativnim predikatom (v. Čaušević 1996: 385-386; 2018: 290-293). Pored toga, u primjeru (3) šutnja nesnalaženja izražava se i participskom atributskom konstrukcijom u kojoj funkciju upravnoga člana preuzima particip na - $(y) A c A k$, koji se dodaje na korijen glagola konuşmak (pričati / ispričati; govoriti / izgovoriti). U prijevodu primjera (3) i (5) šutnja nesnalaženja iskazuje se odnosnom rečenicom u kojoj odrični oblik glagola razgovarati ima funkciju predikata [v. (3)], odnosno modalnom zavisnom klauzom s vezničkom sintagmom a da nije, u kojoj se navodi složeni glagolski predikat s odričnim oblikom faznoga glagola stići u funkciji nepunoznačnoga glagola i potvrdnim oblikom glagola reći u funkciji punoznačnoga glagola [v. (5)] (v. Jahić - Halilović - Palić 2000: 364-365). U primjeru (10) šutnja nesnalaženja izražava se adverbijalnom skupinom s odričnim oblikom konverba na - $(y) \operatorname{Inc} A$, koji se dodaje na osnovu glagola cevap vermek (odgovarati / odgovoriti). S obzirom na to da u ovome primjeru adverbijalna skupina s odričnim oblikom konverba na -(y)IncA ima uzročno značenje (v. Čaušević 2018: 301-302), u prijevodu se šutnja nesnalaženja ispoljava uzročnom klauzom u kojoj odrični oblik glagola odgovoriti preuzima funkciju predikata.

\section{Dugotrajna i neprijatna šutnja}

U originalnome tekstu romana Kafamda Bir Tuhaflık bilježe se primjeri dugotrajne šutnje koja prerasta u tišinu i koja postaje neprijatna i neugodna. Takva se šutnja može definirati kao dugotrajna šutnja (v. Bulić 2018: 167-168).

(11) İstanbul'a dönüş yolunda Mevlut ile Fevziye otobüste hiç konuşmadılar. (KBT: 398) / Na povratku u Istanbul Mevlud i Fevzija u autobusu nisu progovorili ni jednu riječ. (ČMMG: 476)

(12) Bir an Samiha’nın yüzünde bir memnuniyet ifadesi görür gibi oldu. Uzun bir süre konuşmadılar. (KBT: 426) / Učinilo mu se da je na 
trenutak vidio izraz zadovoljstva na Samihinom licu. Šutnja je potrajala. (ČMMG: 509)

(13) Bu hatırlatma ile Samiha, Mevlut'a "Sen beni şimdi daha az seviyorsan, ben de seni o zaman daha az seviyordum," demiş oluyordu. Karı koca arasındaki sessizlik uzun sürdü. (KBT: 456) / To je podsjećanje značilo da mu Samiha želi reći: "Ako ti mene sada manje volišs, i ja sam tebe tada manje voljela." Šutnja između supružnika dugo je potrajala. (ČMMG: 548)

U primjerima (11), (12) i (13) može se vidjeti da je riječ o dugotrajnoj šutnji koja prerasta u tišinu i koja postaje neprijatna i neugodna. U primjeru (11) riječ je o šutnji koja se ostvaruje prilikom povratka Mevluda i njegove mlađe kćeri iz Izmira. U primjeru (12) u pitanju je dugotrajna i neprijatna šutnja koja se ostvaruje nakon što je Mevlud priznao Samihi da je, ipak, njoj pisao ljubavna pisma koja su (ne)namjernom pogreškom adresirana njenoj starijoj sestri. U primjeru (13) realizira se dugotrajna i neprijatna šutnja koja je posljedica Samihine ljubomore prouzrokovane stalnim ispitivanjem da li Mevlud više voli njenu stariju sestru ili nju. Dakle, u primjeru (11) dugotrajna šutnja rezultat je umora likova. S druge strane, u primjerima (12) i (13) dugotrajna i neprijatna šutnja prouzrokovana je neočekivanim priznanjem, odnosno ljubomorom.

U primjerima (11) i (12) i u originalnome tekstu i u prijevodu na bosanski jezik dugotrajna šutnja iskazuje se odričnim oblikom glagola konuşmak (pričati / ispričati; govoriti / izgovoriti). S druge strane, u primjeru (13) i u originalnome tekstu i u prijevodu dugotrajna šutnja izražava se leksemom sessizlik (šutljivost, šutnja). U svim navedenim primjerima može se primijetiti da se upotrebljavaju i prilozi kojima se ukazuje na vremenski tok, odnosno dugotrajnost šutnje.

\section{Šutnja poraza}

Šutnja poraza predstavlja komunikativni resurs kojim se iskazuje predaja i kapitulacija. Zapravo, pragmatička vrijednost navedenoga tipa šutnje jeste priznavanje poraza. Stoga se takva šutnja i definira kao šutnja poraza (v. Bulić 2018: 162). 
(14) "Bozacı, geceleri karanlık sokaklarda korkmaz misın?.. Sıkılmaz misin?.."

"Cenab-1 Allah gariban bozacıya yardım eder. Aklımdan hep güzel şeyler geçer.”

"Geceleri karanlık ücra sokaklarda, mezarlıklar, köpekler, cinler, periler görünce de mi?”

Mevlut sustu. (KBT: 33) /

"Bozadžijo, zar se ne plašiš mraka noću na ulici? Zar ti nije teško?"

"Uzvišeni Bog čuva sirotog bozadžiju. Uvijek mislim samo na lijepe stvari."

"Zar i kada noću u tamnim, zabačenim sokacima ugledaš mezare, pse, džine i vile?”

Mevlud je ušutio. (ČMMG: 39 )

U primjeru (14) Mevlud šutnjom priznaje svoju kapitulaciju i svoj poraz. Naime, Mevlud nikako nije mogao pobijediti strah od pasa. Dok u razgovoru s mušterijama objašnjava sve karakteristike posla kojim se bavi, Mevlud na pitanje da li se, između ostaloga, boji pasa odgovara šutnjom kojom priznaje svoj poraz. Primjećuje se da se i u originalnome tekstu i u prijevodu šutnja kojom se priznaje kapitulacija i poraz iskazuje potvrdnim oblikom glagola susmak (šutjeti / ušutjeti; zašutjeti).

\section{Šutnja protesta}

Šutnja protesta jeste komunikativni resurs kojim se iskazuje pobuna prouzrokovana nezadovoljstvom, neslaganjem ili ljutnjom (v. Bulić 167 :2018).

(15) "Pek de aç birine benzemiyorsun. Nerelisin sen?"

"Beyşehirliyim."

"Beyşehir mi? Neresi orası?”

Mevlut cevap vermedi. (KBT: 38) /

"Ne izgledaš mi baš kao da gladuješ. Odakle si?"

"Iz Bejšehira."

"Iz Bejšehira, gdje ti je to?"

Mevlud mu nije odgovorio. (ČMMG: 45) 
(16) "Hangi iş?” dedi Mevlut, başını televizyondan çevirdi, kalbi hızlandı ama Safiye Teyze hiç ses çıkarmadı. (KBT: 169) / "Šta tetka?", upitao je Mevlud okrenuvši glavu prema televiziji dok mu je srce udaralo kao ludo, ali tetka Safija ništa ne reče. (ČMMG: 198)

(17) "Cevap vermiyor... Aynı herif olmalı. Dikkat et Samiha, şehir maceraperest serseri dolu." Cevap vermezdim. Maceracı serseriyi hımbıl ve şişko zengine tercih ettiğimi Vediha da bilir, anlardı. (KBT: 226) / "Niko se ne javlja... Mora da je to onaj isti. Pazi, Samiha, grad je pun vjetropira i probisvijeta." Nisam ništa odgovarala. I Vediha je znala i shvatala da mi je draži probisvijet od priglupog i debelog bogataša. (ČMMG: 266)

(18) Üç gün sonra Bozkurt bir daha yaptı şakayı. Ben gene kandım; ama sonra tokadı attım yanağına. Şimdi annesiyle konuşmuyor. Evladım kara sevdaya yakalandı, askere de gidecek, dertleniyorum onun için. (KBT: 396) / Za tri dana Bozkurt se još jedanput tako našalio. Ja sam opet nasjela; ali sam ga poslije ošamarila. Sada ne razgovara sa svojom majkom. Pati zbog nesretne ljubavi, treba da ide u vojsku, baš se brinem za njega. (ČMMG: 473)

(19) İzmir'deki kızının yaz boyunca sessiz kalmasından, bir kere bile İstanbul'a gelmemesinden pireleniyordu Mevlut; konuyu kafasindan uzaklaştırıyordu. (KBT: 429) / Uznemiravalo ga je to što mu se kćerka iz Izmira nije javljala cijelo ljeto i što nijedanput nije došla u Istanbul; izbjegavao je o tome razmišljati. (ČMMG: 514)

(20) İçinde sürekli müzik çalan asansörde kayınpederinin bitkin, yorgun ve sessiz hali Mevlut'u üzdü. Ama Samiha'ya kırılmıştı; aşağıda, kendi dairelerinde boza takımlarını aldı ve karısına hiçbir şey demeden hevesle, mutlulukla sokaklara çıktı. (KBT: 463) / Silazeći liftom u kojem je uvijek svirala muzika rastužio se vidjevši kako mu je punac iscrpljen i šutljiv. Ali bio je ljut na Samihu; dolje je uzeo opremu za bozu i ništa joj ne rekavši, izašao sretan i pun poleta na ulice. (ČMMG: 556)

U primjerima od (15) do (20) pragmatička vrijednost šutnje jeste pobuna koja je prouzrokovana nezadovoljstvom i ljutnjom. U primjeru (15) pragmatička vrijednost šutnje jeste pobuna prodavača boze koja je prouzrokovana ljutnjom na mušteriju koja ne zna gdje se nalazi njegovo rodno mjesto. U primjeru (16) šutnjom se označava protest tetke 
Safije, koja je ljuta na Mevluda, koji je ne sluša dok mu ona upućuje jako korisne savjete u vezi sa životnim iskustvom. U primjeru (17) šutnjom se iskazuje pobuna Samihe, koja je ljuta na članove svoje porodice jer svi žele da se ona uda za bogatoga rođaka Sulejmana. Dakle, u ovome primjeru ilokucija šutnje jeste pobuna protiv tradicionalnih postulata sociokulturne stvarnosti. U primjerima (18) i (19) pragmatička ilokucija šutnje jeste pobuna protiv autoriteta. U primjeru (18) šutnjom se izražava pobuna dječaka Bozkurta, koji je ljut na majku jer ga je ošamarila nakon jedne njegove šale. U primjeru (19) šutnjom se označava pobuna kćeri protiv oca koji se, nakon suprugine smrti, oženio svojom svastikom. U primjeru (20) šutnjom se iskazuje pobuna Mevluda, koji je ljut na Samihu jer je cijeloj porodici otkrila tajnu da se žele preseliti.

Primjećuje se da se i u originalnome tekstu i u prijevodu šutnja protesta iskazuje odričnim oblikom glagola cevap vermek (odgovarati / odgovoriti) [v. (15) i (17)] i konuşmak (pričati / ispričati; govoriti / izgovoriti) [v. (18)]. U primjeru (16) u originalnome tekstu šutnja protesta iskazuje se frazemom ses çıkarmamak, dok se u prijevodu koristi odrični oblik glagola reći. Frazem ses çıkarmamak povezuje se s konceptom šutnje i značenjski je blizak bosanskim glagolima šutjeti / prešutjeti, ne govoriti (https://sozluk.gov.tr/: posjet: 2. 12. 2020). U primjeru (19) u originalnome tekstu šutnja protesta izražava se kompozitnim glagolom sessiz kalmak, koji je značenjski blizak bosanskim glagolima ostajati / ostati bez glasa, šutjeti / ušutjeti, ne progovarati / ne progovoriti, ne javljati se / ne javiti se. Stoga se u prijevodu šutnja protesta iskazuje odričnim oblikom glagola javljati se. U primjeru (20) u originalnome tekstu šutnja protesta označava se konverbom na $-m A d A n$, koji se dodaje na korijen glagola demek (govoriti; reći). Već je navedena konstatacija da se konverbom na - $m A d A n$ označavaju način i okolnosti vršenja radnje koja se izražava korelativnim predikatom, a s obzirom na to da je navedeni konverb značenjski blizak odričnome obliku bosanskoga glagolskog priloga sadašnjeg ili prošlog, u prijevodu se šutnja protesta ispoljava glagolskim prilogom prošlim. 


\section{Šutnja u nesreći}

Šutnja u nesreći jeste komunikativni resurs kojim se označava tuga, bol i žalost. Takav se oblik šutnje realizira u nesreći koja je zadesila likove (v. Bulić 2018: 166).

(21) Biri yaşlı öbürü genç iki soyguncu uzaklaşırken Mevlut hiç sesini çıarmadan arkalarından baktı. (KBT: 40) / Dok su se dva pljačkaša, jedan mlađi, a drugi stariji, udaljavali, Mevlud je bez riječi pogledao za njima. (ČMMG: 47)

(22) Canım melek kardeşim Rayiha, mekânı cennet olsun, bana ve Mevluta iki yalan söylemiş, şimdi anladım. Bana, Mevlut'un bebeği aldırmak istediğini söylemişti, doğru değilmiş. Mevluta bebeğin kız olacağını söylemiş, bu da tabii daha belli değildi. Ama acımız o kadar büyük ki, kimsenin konuşup bir şey anlatabileceğini sanmam. (KBT: 349) / Draga moja sestrice, meleku, Rajiha, neka ti Allah podari Džennet, sad sam shvatila da je meni i Mevludu rekla dvije laži. Meni je rekla da se Mevlud želi riješiti djeteta, a to nije bilo istina, a Mevludu je rekla da će beba biti djevojčica što se, naravno, još uvijek nije moglo znati. Ali naša je bol tako velika da ne mislim da će iko biti u stanju nešto pričati i objašnjavati. (ČMMG: 414)

(23) Acaba sebzeli yemeğe biraz daha et mi koysaydım? Çünkü ağlamaktan yorulanlar mutfağa gelip, tencerelerin kapağını kaldırıp içine uzun uzun sessizce bakiyorlard. (KBT: 349) / Jesam li trebala u jelo s povrćem staviti malo više mesa? Jer oni koji bi se umorili od plakanja dolazili su u kuhinju, podizali poklopac lonca i dugo, ništa ne govoreći, zurili unutra. (ČMMG: 415)

(24) Kayalık topraklardaki küçük yeşilliklere, bulutlar arasından güneşin aydınlattığı sapsarı tarlalara, uzaktan bir çizgi gibi gözüken göle, servili mezarlıklara bakarlarken aralarında uzun sessizlikler olurdu. Uzaklardan köpekler havlardı. Mevlut dönüş otobüsünde, köy manzaralarının kendisine hep Rayiha’yı hatırlatacağını anladı. (KBT: 353-354) / Među njima bi zavladao muk dok su gledali u male krpice zelenila na kamenitom zemljištu, potpuno žute njive koje je obasjavalo sunce između oblaka, jezero u daljini nalik na liniju i mezarja s čempresima. 
Negdje daleko lajali su psi. Mevlud je na povratku, u autobusu, shvatio da će ga seoski pejsaži uvijek podsjećati na Rajihu. (ČMMG: 420)

U primjerima (21), (22), (23) i (24) šutnjom se označavaju tuga, bol i žalost u nesreći koja je zadesila likove. U primjeru (21) šutnjom se izražava bol i tuga Mevluda u nesreći koja ga je zadesila nakon što su ga razbojnici opljačkali. S druge strane, u primjerima (22), (23) i (24) šutnjom se iskazuje bol i tuga cijele porodice u nesreći koja ih je zadesila nakon što je Rajiha preminula.

I u ovim se primjerima može vidjeti da se šutnja iskazuje frazemom ses çıkarmamak (šutjeti / prešutjeti, ne govoriti) [v. (21)], odnosno kompozitnim glagolom sessizlik olmak (nastupati / nastupiti tišina; zavladati tišina; zavladati muk) [v. (24)]. U primjeru (23) šutnja u nesreći ispoljava se prilogom sessizce (nečujno, tiho), dok se u prijevodu koristi glagolski prilog sadašnji. U primjeru (22) i u originalnome tekstu i u prijevodu šutnja u nesreći izražava se pretpostavkom da niko neće biti u stanju tražiti razloge koji su doveli do nesreće.

\section{Šutnja unutarnjega previranja}

Šutnja unutarnjega previranja ukazuje na emotivno stanje koje svojim intenzitetom sprečava ljude da ispolje svoje emocije (v. Bulić :2018 169-168).

(25) Sabah kamyonetle giderken Mevlut çok keyifliydi, şakalar yapıyor, her gördüğü fabrikaya, köprüye merakla bakıyor, "Gaza bas, daha hızlı," diyor, konuşuyor da konuşuyordu. Bir süre sonra sesi soluğu kesildi. (KBT: 171) / Ujutro, kada su krenuli kamionetom, Mevlud je bio dobro raspoložen, šalio se, sa zanimanjem razgledao svaki most i fabriku pored koje bi prošli te stalno uzvikivao: "Daj gas, brže, brže." Nešto kasnije, prestao je pričati. (ČMMG: 200)

(26) Bazan bu çeşitlerden biri gecenin sonunda Mevlut Rayiha'yı iyice özlerken biter, bir müşteri "Vişne yok," diyen Mevlut'a "O zaman niye yazıyorsun vişne?" diye ukalalık eder, Mevlut da "Bitti," demez, "Ben yazmadım ki," demek ister, ama Rayiha’yı düşünüp mutlu olduğu için cevap bile vermezdi. (KBT: 187) / Ponekad je, kad bi Mevlud uvečer 
silno poželio Rajihu, znalo nestati neke od tih vrsta sladoleda te bi mušterije na Mevludove riječi: "Nema višnje”, nadmeno govorile: "Pa zašto onda pišeš višnja?” Mevlud ne bi rekao: "Nestalo je”, već bi poželio reći: "Nisam ja to napisao", no kako je bio sretan jer je mislio na Rajihu, samo bi šutio. (ČMMG: 218)

(27) Beni filmlerdeki gibi öptü. Hayatımda ilk defa bir erkekle dudaktan öpüştüğüm için kafam karıştı ve söze devam edemedim. (KBT: 228) / Poljubio me je kao u filmu. Pomutilo mi se u glavi i nisam mogla nastaviti govoriti jer sam se prvi put u svom životu ljubila s muškarcem u usta. (ČMMG: 268)

U primjerima (25), (26) i (27) može se primijetiti da se šutnjom ukazuje na emotivno stanje koje svojim intenzitetom sprečava likove da ispolje svoje emocije. U primjeru (25) šutnjom se označava Mevludovo uzbuđenje u trenucima kada je krenuo na put da "ukrade" Rajihu. U primjeru (26) šutnjom se ukazuje na Mevludovo emotivno stanje prouzrokovano razmišljanjem o suprugi, dok se u primjeru (27) šutnjom označava Rajihino uzbuđenje nakon što se prvi puta poljubila sa svojim suprugom.

U primjerima (25) i (27) i u originalnome tekstu i u prijevodu šutnja unutarnjega previranja iskazuje se kompozitnim glagolskim formama sesi kesilmek (šutjeti / ušutjeti; prestati pričati) [v. (25)] i söze devam edememek (ne moći nastaviti govoriti) [v. (27)]. S druge strane, u primjeru (26) u originalnome tekstu šutnja unutarnjega previranja izražava se odričnim oblikom glagola cevap vermek (odgovarati / odgovoriti), dok se u prijevodu upotrebljava potvrdni oblik glagola šutjeti.

\section{Šutnja provjeravanja}

Šutnja provjeravanja predstavlja komunikativni resurs kojim se provjerava utjecaj prethodno izgovorenih riječi.

(28) Müdire Aysel bir an sustu, sözlerinin etkisini Mevlut'un sınıf arkadaşlarının yüzlerinde görmeye çalıştı. (KBT: 84) / Bibliotekarka Ajsel je na trenutak zašutjela trudeći se da vidi kakav su utisak ostavile njene riječi na Mevludove drugove iz razreda. (ČMMG: 97) 
U primjeru (28) primjećuje se da je pragmatička vrijednost šutnje provjeravanje utjecaja prethodno izgovorenih riječi. Naime, u ovome primjeru bibliotekarka šutnjom provjerava i utvrđuje da li su učenici, odnosno posjetioci biblioteke na najbolji način interpretirali njene prethodno izgovorene riječi u vezi s pravilima ponašanja u biblioteci. Primjećuje se da se i u originalnome tekstu i u prijevodu šutnja provjeravanja izražava potvrdnim oblikom glagola susmak (šutjeti / ušutjeti; zašutjeti).

\section{Šutnja o tabu temama}

Ovaj tip šutnje predstavlja šutnju kojom se izbjegavaju neugodne teme koje bi mogle prouzrokovati neugodne situacije. Stoga se takva šutnja može nazvati šutnjom o tabu temama (v. Bulić 2018: 163-164).

(29) Sabah çarşafların üzerinde vişne renginde lekeler görünce Mevlut ile Rayiha hem utandılar hem de bu, Rayiha’nın bakire olduğunun beklenen işareti olduğu için, duygularını birbirlerine göstermeden sevindiler. Bu konuyu hiç konuşmadılar, ama Mevlut yaz boyunca akşamları satacağı dondurmayı Rayiha ile birlikte hazırlarken sabahları bu renk benzerliğini hep hatırladı. (KBT: 185) / Ujutro, kada su na čaršafu ugledali mrlje boje višnje, oboje su, krišom jedno od drugoga, osjetili stid ali i radost jer je to bio znak da je Rajiha djevica. O tome nisu nikada govorili, ali Mevlud se cijelo ljeto prisjećao tog jutra zbog sličnosti u boji sa sladoledom od višnje koji bi pripremao s Rajihom za večernju prodaju. (ČMMG: 216)

(30) Kimse hatırlamak, söylemek istemiyordu, ama eskiden Tarlabaşı bir Rum-Ermeni-Yahudi ve Süryani mahallesiydi. (KBT: 258) / Niko se nije želio sjećati i govoriti o tome, ali nekada je mahala Tarlabaši pripadala Grcima, Armencima, Jevrejima i Asircima. (ČMMG: 306)

(31) Konu bir daha hiç konuşulmadı. Mevlut resmi ret cevabını kimsenin kalbini kırmadan nasıl vereceğini bilemediği için Süleyman’ aramadı. (KBT: 394) / Više nikada o tome nisu pričali. Mevlud nije potražio Sulejmana zato što nije znao kako da ih zvanično odbije a da nikoga ne povrijedi. (ČMMG: 471) 
(32) Mevlut 11 Eylül günü Amerika'daki gökdelenlere uçakların çarpmasını ve binaların alevler ve dumanlar arasında filmlerdeki gibi çökmesini Fevziye ile televizyonda defalarca izledi. Mevlut'un sesini yükseltmeden söylediği "Şimdi Amerika bunun intikamını alır!" gibi bir söz dışında olay hakkında hiç konuşmadılar. (KBT: 399) / Mevlud je s Fevzijom više puta na televiziji gledao kako su 11. septembra avioni udarili u nebodere u Americi i zgrade se, baš kao u filmovima, srušile u plamenu i dimu. O tome nisu uopće razgovarali osim što je Mevlud, ne povisujući glas, rekao: "Sad će se Amerika osvetiti za to!" (ČMMG: 477)

(33) Sadullah Bey'i kahvede bulmuş, ama Efendi Hazretleri ve dergâhtan hiç söz etmemişti ona. (KBT: 414) / Našavši gospodina Sadullaha u kafani, ništa mu ne bi rekao o šejh-efendiji i tekiji. (ČMMG: 495)

(34) Mevlut aracılık eden kızının dikkatli, dertli bakışlarını görüyordu. "Yanlış yaptık," dedi kederle.

"Evet," dedi kızı.

Konu baba kız arasında uzun bir süre açılmadı. (KBT: 419) /

Mevlud je gledao u pažljive i zabrinute poglede svoje kćerke koja je bila posrednik. "Pogriješili smo", rekao je tužno.

"Da", potvrdila je kćerka.

Dugo nisu o tome razgovarali. (ČMMG: 501)

(35) Bir iki kere de Süleyman’n inşaat şirketinin kamyonu geldi, ama Mevlut bu destekten Samiha’ya hiç söz etmedi. Herkesle iyi geçinmek için çırpınıyor, evliliğine kimse burun kıvırmasın istiyordu. (KBT: 429) / Nekoliko puta je došao i kamion iz Sulejmanovog građevinskog poduzeća, ali o toj pomoći Mevlud nije ništa rekao Samihi. Upinjao se da se sa svima dobro slaže i nije želio da iko negoduje zbog njihovog vjenčanja. (ČMMG: 514)

U primjeru (29) Mevlud i Rajiha šutnjom izbjegavaju razgovor o svome prvom ljubavnome iskustvu. Dakle, šutnjom se označava sramežljivost likova u vezi s njihovim prvim ljubavnim iskustvom. U primjeru (30) šutnjom se izbjegava razgovor o neugodnim temama u vezi s određenim kolektivnim pogreškama iz prošlosti. Stoga se u ovome primjeru šutnjom i priznaju određene kolektivne pogreške iz prošlosti. U primjeru (31) šutnjom se ukazuje na izbjegavanje razgovora o eventualnome 
braku između dvoje rođaka, Mevludove kćeri i Sulejmanovoga sina. $\mathrm{Na}$ temelju tradicionalnih postulata sociokulturne stvarnosti u kojoj egzistiraju, članovi porodice implicitno insistiraju na ovome braku. Međutim, šutnja o ovoj temi predstavlja i svojevrsnu Mevludovu podršku kćeri koja se suprotstavlja takvome braku. Zapravo, pragmatička vrijednost šutnje jeste i pobuna protiv tradicionalnih postulata sociokulturne stvarnosti, zbog čega se ova šutnja može svrstati i u okvire šutnje protesta. U primjeru (32) šutnjom se označava izbjegavanje neugodne teme koja bi mogla prouzrokovati poteškoće cijelome društvu u budućnosti. Dakle, pragmatička ilokucija šutnje jeste kolektivna zabrinutost. U primjerima (33), (34) i (35) šutnjom se izbjegavaju teme koje bi mogle prouzrokovati neslaganje sa sagovornikom te je ilokucija šutnje izbjegavanje neslaganja sa sagovornikom, što predstavlja jednu od strategija pozitivne učtivosti kojom se omogućavaju i održavaju dobri odnosi među sagovornicima (v. Bakšić 2012: 72-75; Bakšić - Bulić 2019: 203). Naime, u primjeru (33) Mevlud šutnjom izbjegava razgovor o vjerskim temama kada je u društvu s poznanikom koji ne prakticira vjerske propise i koji osjeća i određeni animozitet prema ljudima koji se pridržavaju tih propisa. S druge strane, u primjerima (34) i (35) šutnjom se izbjegava razgovor o Sulejmanovoj pomoći, prvenstveno zato što Samiha osjeća animozitet prema Sulejmanu i spominjanje ove teme izazvalo bi nesuglasice s njom.

Može se uočiti da se u originalnome tekstu šutnja o tabu temama iskazuje različitim sintaksičkim konstrukcijama, dok se u prijevodu na bosanski jezik takva šutnja u svim primjerima izražava konstrukcijom sastavljenom od prijedloga $o$ i lokativa.

\section{Šutnja odobravanja}

Šutnja odobravanja jeste komunikativni resurs kojim se potvrđuju i odobravaju postupci govornika (v. Bulić 159-158 :2018).

(36) Saray Sineması'nda film seyrederken, babamla Vediha Süleyman’nn doğrudan benim yanıma oturmasına ses çıkarmadıkları için filmin ortasında, Süleyman’n eli bacağımın kenarına ihtiyatlı bir yengeç gibi 
bilerek mi sokuluyor, bu bir tesadüf mü, dikkat etmiş, bir sonuca varamamıştım. (KBT: 203) / Kako otac i Vediha nisu ništa rekli kada je u kinu Sulejman sjeo odmah pored mene, nisam mogla procijeniti da li se slučajno ili namjerno usred filma njegova ruka poput raka zakačila za moju nogu. (ČMMG: 236)

(37) Ama Mevlut merak etmemeliydi, çetenin ona ve buraya park etmiş arabalara bir kötülük yapma niyeti yoktu. Mevlut reklam şirketinin park yeri boşsa, genç Kemal'in dışarıdan birkaç araba getirip park etmesine ses çıkarmaz, ama bu ayrıntıları yukarıya Damat’a arada rapor ederdi. (KBT: 347) / Ali Mevlud se nije morao brinuti, banda nije namjeravala učiniti ništa loše njemu ili automobilima koji su tu bili parkirani. Ništa ne bi rekao ni kada bi mladi Kemal izvana dovezao nekoliko automobila na upražnjena mjesta njegovog parkinga, ali bi o tim pojedinostima povremeno obavijestio one gore, odnosno Mladoženju. (ČMMG: 412)

(38) “Bütün hayatım boyunca alttan aldım onlara," dedi Mevlut. Samiha susunca cesaretlendi. "Şimdi dikbaşlllık edersem bu daire de gidebilir. Bunun sorumluluğunu alıyor musun? Ablanı geri ara, işi tatlıya bağla, ben korktum onlardan, pişmanım." (KBT: 444) / "Cijeli život sam im popuštao", rekao je Mevlud. Ohrabrio se kada je Samiha ušutjela. "Ako se sada usprotivim, može otići i taj stan. Preuzimaš li ti svu odgovornost za to? Sad ti nazovi sestru, izgladi stvar; uplašili su me i sad se kajem." (ČMMG: 533)

U primjerima (36), (37) i (38) može se vidjeti da je pragmatička vrijednost šutnje potvrđivanje i odobravanje postupaka govornika. U primjeru (36) primjećuje se da Abdurahmanova i Vedihina šutnja označava odobravanje Sulejmanovih postupaka kojima se on nastoji približiti Samihi. Cijela je porodica pokušavala ubijediti Samihu da treba stupiti u brak sa Sulejmanom, a Abdurahman i Vediha šutnjom odobravaju Sulejmanove postupke kojima se on pokušava zbližiti s njihovom kćeri, odnosno sestrom. U primjeru (37) uočava se kako Mevludova šutnja označava odobravanje postupaka mladoga Kemala, koji parkira automobile na parking koji je Mevlud čuvao. U primjeru (38) može se vidjeti da Samihina šutnja označava odobravanje Mevludovoga ponašanja, koji je čvrsto odlučio da će se strožije i odlučnije ponašati prema svojim 
rođacima, za koje je konačno shvatio da iskorištavaju njegovu pasivnost i nezainteresiranost.

U primjerima (36) i (37) u originalnome tekstu šutnja odobravanja izražava se frazemom ses çıkarmamak, za koji je već navedena konstatacija da se povezuje s konceptom šutnje te da je značenjski blizak bosanskim glagolima šutjeti / prešutjeti, ne govoriti. Stoga se u prijevodu oba primjera koristi odrični oblik glagola reći. U primjeru (38) i u originalnome tekstu i u prijevodu šutnja odobravanja izražava se glagolom susmak (šutjeti / ušutjeti; zašutjeti).

\section{Šutnja suzdržavanja}

Ovaj tip šutnje predstavlja šutnju kojom se izbjegava potencijalni sukob. Stoga se takva šutnja može definirati kao šutnja suzdržavanja (v. Bulić 2018: 161).

(39) Ertesi hafta Mevlut dedikoduculardan, Şişman ve Vahit'in kendisine çok öfkeli olduklarını, Mevlut'tan hem avantadan pay alan hem de çalışanları patrona ihbar eden bir fırsatçı olarak söz ettiklerini de işitti, ama bu iftiralara karşı sessiz kaldı. (KBT: 303-304) / Sljedeće sedmice je čuo i to da su Debeli i Vahid ljuti na njega, da pričaju o Mevludu kao o prepredenjaku koji je uprkos tome što je uzeo novac za šutnju, zaposlenike prijavio gazdi. Ali na te klevete nije ništa rekao. (ČMMG: 361)

(40) Rayiha’nın kocasına iş ayarlayan girgin halini sevmedi Mevlut. Ama başkalarında hata bulup huysuzluk edecek gücü yoktu o anda. Sesini çıkarmadı. (KBT: 312) / Mevludu se nije svidjelo Rajihino predusretljivo ponašanje kako bi mužu pomogla da nađe posao. U tom trenutku nije imao snage da drugima zamjera i joguni se. (ČMMG: 371)

(41) "Hasta kız tabii yok, öyle değil mi?"

"Ne kızı be ağbi... Daha evlenmediler bile... Sürmeneli'nin bir de köyde karısı, ondan yetişkin oğulları var. Oğullar da biliyorlar Hanımefendi’yi ama ses etmiyorlar." (KBT: 331) /

"Nema ni bolesnu kćerku, je l' tako?"

"Kakvu kćerku, bolan ne bio... Još se nisu ni vjenčali. On na selu ima ženu i s njom odrasle sinove. I sinovi znaju za gospođu ali mu ne prigovaraju." (ČMMG: 393) 
(42) Konu rahatsız edici bir noktaya geldiği için karı koca sustular ama masadan kalkmadılar. (KBT: 456) / Supružnici su ušutjeli jer su došli do opasne tačke u svom razgovoru, ali su ostali sjediti za stolom. (ČMMG: 548)

U primjerima (39), (40), (41) i (42) uočava se da je pragmatička ilokucija šutnje suzdržavanje kojim se izbjegava potencijalni konflikt. U primjeru (39) Mevludova šutnja označava suzdržavanje i nereagiranje na ogovaranje i klevete koje mu bivše kolege upućuju. Na taj način Mevlud izbjegava potencijalni konflikt sa svojim bivšim kolegama. U primjeru (40) pragmatička vrijednost Mevludove šutnje jeste suzdržavanje i nereagiranje na ponašanje supruge koja mu pokušava pronaći posao. I u ovome primjeru Mevlud šutnjom izbjegava potencijalni sukob sa svojom suprugom. U primjeru (41) pragmatička ilokucija šutnje jeste suzdržavanje i nereagiranje mladića koji znaju da im otac ima ljubavnicu. Na taj način oni izbjegavaju konflikt s ocem, ali sprečavaju i potencijalni sukob između svojih roditelja. U primjeru (42) Mevludova i Samihina šutnja označava suzdržavanje kojim se prekida razgovor koji bi mogao izazvati sukob. Može se primijetiti da u svim navedenim primjerima pragmatička vrijednost šutnje jeste suzdržavanje kojim se, zapravo, izbjegava neslaganje sa sagovornikom, a to se može okarakterizirati kao strategija pozitivne učtivosti kojom se održavaju dobri odnosi među sagovornicima (v. Brown - Levinson 1987: 115).

U primjerima (39), (40) i (41) primjećuje se da se šutnja suzdržavanja iskazuje kompozitnim glagolima sessiz kalmak (ostajati / ostati bez glasa, šutjeti / ušutjeti, ne progovarati / ne progovoriti, ne javljati se / ne javiti se) [v. (39)], ses çıkarmamak (šutjeti / prešutjeti, ne govoriti) [v. (40)] i ses etmemek (šutjeti / ušutjeti; zašutjeti) [v. (41)], dok se u prijevodu upotrebljavaju glagoli reći [v. (39)] i prigovarati [v. (41)] u odričnome obliku. U primjeru (40) može se vidjeti da se i ne prevodi kompozitni glagol ses çıkarmamak, prvenstveno zato što se šutnja suzdržavanja označava u prethodnim rečenicama. U primjeru (42) i u originalnome tekstu i u prijevodu šutnja suzdržavanja izražava se glagolom susmak (šutjeti / ušutjeti; zašutjeti). 


\section{Šutnja neznanja}

$S$ obzirom na to da se ovim tipom šutnje označava neznanje u vezi s određenom temom, ovakva se šutnja može definirati kao šutnja neznanja (v. Bulić 2018: 161).

(43) Bu üçüncü cümleyi yazdıkları gecelerin birinde, Mardinli bulaşıkçıların daha rahat ve iyimser olanı "Ağbi gerçekten sen bu kızı bütün gün düşünüyor musun?” diye sordu ve Mevlut'un bir an sessiz kaldığını görünce de özür diler gibi, sorusunu açıkladı: "En sonunda, bir an gördüğün kızın nesini düşüneceksin ki?” (KBT: 149) / Jedne noći, dok su smišljali treću rečenicu, slobodniji i optimističniji mladić iz Mardina upitao je: "Brate, misliš li ti stvarno cijeli dan na tu djevojku?", a kad nije dobio odgovor, dopunio je pitanje: "Konačno, o čemu i možeš misliti kad si djevojku vidio samo nakratko?” (ČMMG: 175)

U primjeru (43) Ferhat pomaže Mevludu u sastavljanju ljubavnoga pisma, a Mevludova šutnja označava njegovo neznanje u sastavljanju takvih pisama. Može se primijetiti da se u originalnome tekstu šutnja neznanja iskazuje kompozitnim glagolom sessiz kalmak (ostajati / ostati bez glasa; šutjeti / ušutjeti; ne progovarati / ne progovoriti; ne javljati se / ne javiti se), dok se u prijevodu koristi sintagma ne dobiti odgovor.

\section{Zahtijevana šutnja}

U ovaj tip šutnje može se uvrstiti šutnja koju likovi zahtijevaju jedni od drugih. Takav tip šutnje najčešće zahtijevaju likovi koji su u nadređenome društvenom statusu u odnosu na sagovornike (v. Bulić 2018: 161).

(44) Bir torpili olduğunu sürekli söylemenin diğer erlerin saldırganlık ve alaycılıklarına karşı kendini koruyacağını da böylece ilk günden kavradı. Sıradaki kendi gibi bıyıklı (iyi ki bıyık bırakmışım diye düşünüyordu Mevlut) birine Hacı Hamit Vural’ı herkesin tanıdığını, onun çok adil ve yardımsever bir hayırsever olduğunu anlatıyordu ki "Susun!" diye bağırdı sıradakilere bir komutan. (KBT: 155) / Već prvog dana shvatio je da ćeš izbjeći podsmijeh i napade vojnika ako stalno govoriš da imaš "vezu". Upravo dok je brki pored sebe pričao (Mislio je: "Dobro je da sam pustio brkove”) kako Hadži Hamid Vural poznaje svakog živog, 
da je veoma pravedan, plemenit i uvijek spreman pomoći, komandant povika na sve one koji su čekali u redu: “Tišina!" (ČMMG: 181)

U primjeru (44) šutnja je prouzrokovana naredbom, odnosno zahtjevom komandanta koji je u nadređenom položaju u odnosu na vojnike kojima je naredba upućena. Primjećuje se da se u originalnome tekstu imperativnom formom glagola susmak (šutjeti / ušutjeti; zašutjeti) ukazuje na zahtijevanu šutnju. S druge strane, u prijevodu se na zahtijevanu šutnju upućuje leksemom tišina.

\section{Šutnja prihvatanja krivice}

Šutnjom se može označavati i priznavanje krivice, a takav se tip šutnje može definirati kao šutnja prihvatanja krivice.

(45) "Samiha, babam eve dönünce inme iner ona," dedim. "Süleyman'dan takma dişleri için, başka bir sürü şey için para ve hediye aldı, biliyorsun. Bunu babacığımıza yapacak mısın?" Cevap vermedi, önüne bakıyordu. (KBT: 206) / "Samiha, kad se otac vrati kući, poludjet će. Znaš da je od Sulejmana uzeo pare za protezu i još sto drugih stvari. Zar možeš tako nešto učiniti ocu?", upitala sam. Ništa nije odgovorila, samo je gledala ispred sebe. (ČMMG: 241)

U primjeru (45) pragmatička vrijednost šutnje jeste prihvatanje krivice. U navedenome primjeru Samihina šutnja označava prihvatanje krivice za nezavidan položaj u kojem su se našli članovi njene porodice, prvenstveno zato što se ona ne želi udati za Sulejmana, koji im pruža i materijalnu pomoć. Uočava se da se i u originalnome tekstu i u prijevodu šutnja prihvatanja krivice iskazuje odričnim oblikom glagola cevap vermek (odgovarati / odgovoriti).

\section{Šutnja o posvjedočenome}

Šutnja o posvjedočenome jeste komunikativni resurs kojim se sprečava širenje informacija u vezi s nekom tajnom (v. Bulić 165-164 :2018).

(46) Evet, Ferhat'a kaçtığım doğru. Yerimizi belli etmemek için iki yıl oldu susuyorum. (KBT: 225) / Da, istina je pobjegla sam s Ferhatom. Ima već dvije godine kako šutim da ne bih otkrila gdje se nalazimo. (ČMMG: 265) 
U primjeru (46) pragmatička vrijednost šutnje jeste sprečavanje širenja informacija u vezi s određenom tajnom. Naime, u navedenome primjeru Samihina šutnja označava sprečavanje širenja informacija u vezi s mjestom gdje Ferhat i ona borave, a otkrivanje jedne takve tajne moglo bi im prouzrokovati velike probleme. Primjećuje se da se i u originalnome tekstu i u prijevodu šutnja o posvjedočenome izražava potvrdnim oblikom glagola susmak (šutjeti / ušutjeti; zašutjeti).

\section{Šutnja položaja}

U ovaj tip šutnje uvrštava se šutnja koja je prouzrokovana podređenim socijalnim statusom likova u odnosu na govornika. Stoga se takva šutnja može nazvati šutnjom položaja (v. Bulić 2018: 164).

(47) “Duttepe köy ise Duttepe Hacı Hamit Vural'ın camii de Türkiye’nin en büyük köy camii olsun,” dedim. Cevap bile vermediler. (KBT: 96) / "Ako je Duttepe selo, nek džamija Hadži Hamida Vurala na Duttepeu bude najveća seoska džamija u Turskoj”, rekao sam. Nisu mi ni odgovorili. (ČMMG: 112)

(48) Bir torpili olduğunu sürekli söylemenin diğer erlerin saldırganlık ve alaycılıklarına karşı kendini koruyacağını da böylece ilk günden kavradı. Sıradaki kendi gibi bıyıklı (iyi ki bıyık bırakmışım diye düşünüyordu Mevlut) birine Hacı Hamit Vural'ı herkesin tanıdığını, onun çok adil ve yardımsever bir hayırsever olduğunu anlatıyordu ki "Susun!" diye bağırdı sıradakilere bir komutan. Hepsi titreyerek sustular. (KBT: 155) / Već prvog dana shvatio je da ćeš izbjeći podsmijeh i napade vojnika ako stalno govoriš da imaš "vezu”. Upravo dok je brki pored sebe pričao (Mislio je: "Dobro je da sam pustio brkove”) kako Hadži Hamid Vural poznaje svakog živog, da je veoma pravedan, plemenit i uvijek spreman pomoći, komandant povika na sve one koji su čekali u redu: “Tišina!" Svi su zadrhtali i ušutjeli. (ČMMG: 181)

(49) Şişlide çok kibar, çok zengin bir ev, benim gibi çalışkan, dürüst ve güvenilir bir kadın arıyordu. Beni yollayacaktı Nalan Hanım, ben de hiç sesimi çıarmadan hemen gitmeliydim. (KBT: 236) / Na Šišliju je jedna ugledna, jako bogata kuća tražila vrijednu, čestitu i pozdanu ženu 
poput mene. Gospođa Nalan me je namjeravala poslati njima i ja sam odmah, bez pogovora, morala krenuti. (ČMMG: 278)

U primjerima (47), (48) i (49) uočava se da je šutnja prouzrokovana podređenim socijalnim statusom likova. U primjeru (47) Hadži Hamid Vural, bogati građevinski poduzetnik, saopćava mještanima razloge zbog kojih je odlučio sagraditi veliku i raskošnu džamiju u njihovome naselju. Šutnja mještana može se činiti kao šutnja odobravanja. Međutim, mještani se ne slažu s ovom idejom u vezi s gradnjom velike i raskošne džamije, ali to, ipak, ne smiju javno kazati, prvenstveno zato što su u podređenome društvenom položaju u odnosu na bogatoga poduzetnika od kojega u velikoj mjeri zavise i životne sudbine njihovih porodica. U primjeru (48) šutnja je kao usud dodijeljena vojnicima koji su u podređenome društvenom položaju u odnosu na komandanta koji zahtijeva od njih da šute. Dakle, u ovome se primjeru javljaju dva oblika šutnje, i to zahtijevana šutnja i šutnja položaja. U primjeru (49) riječ je o šutnji koja je kao usud dodijeljena služavki koja je, zapravo, marginalizirani lik u odnosu na svoju gazdaricu.

U primjerima (47) i (48) primjećuje se da se i u originalnome tekstu i u prijevodu na bosanski jezik šutnja položaja iskazuje odričnim oblikom glagola cevap vermek (odgovarati / odgovoriti) [v. (47)], odnosno potvrdnim oblikom glagola susmak (šutjeti / ušutjeti; zašutjeti) [v. (48)]. U primjeru (49) uočava se da se u originalnome tekstu šutnja položaja izražava frazemom ses çıkarmamak (šutjeti / prešutjeti, ne govoriti), dok se u prijevodu koristi sintagma bez pogovora.

\section{Šutnja tajnovitosti}

Šutnja tajnovitosti jeste komunikativni resurs čija je pragmatička vrijednost tajnovitost ili sakrivanje u određenim kontekstualnim situacijama.

(50) "Yarın akşam misafir var, sekiz on bardak boza bekliyoruz," dedikten sonra, ertesi akşam kapı duvar sessizliğe bürünüp, soğukta zili çalan Mevlut’a kapı bile açmayan alçaklara öfkeleniyordu. (KBT: 257) / Nervirao se i kada bi se Fatma i Fevzija posvađale dok bi gledale 
televiziju i kada bi prvo počele vikati, a zatim plakati. Ljutio bi se i na pokvarenjake koji bi se, nakon što su rekli: "Sutra imamo goste, očekujemo osamnaest čaša boze", sljedeću večer ušutjeli ostavljajući ga da na hladnoći uporno zvoni ne otvorivši vrata. (ČMMG: 304)

(51) Mevlut ilk ziyaretinden neredeyse bir yll sonra, Efendi Hazretleri'nin öğrencilere eski yazıyı ve hat sanatını öğretmek için özel dersler verdiği evinin aynı zamanda ona hayran küçük bir müminler kalabalığının toplandığı bir dergâh olduğunu anladı. Bunu bu kadar geç öğrenmesinin nedeni, dergâha - apartman dairesine - gidip gelenlerin sırseverliği ve sessizliği kadar, kendisinin de bu konuları öğrenmek istemeyişiydi. (KBT: 291) / Mevlud je gotovo godinu dana nakon prve posjete shvatio da je kuća šejh-efendije u kojoj je on svojim učenicima davao privatne časove kaligrafije istovremeno i tekija gdje se skupljala mala skupina vjernika, šejhovih sljedbenika. Razlog zbog kojeg je to tako kasno shvatio ležao je koliko u tajnovitosti i šutliivosti posjetilaca toliko i u tome što on sâm o tim stvarima nije želio ništa znati. (ČMMG: 346)

(52) Ferhat konuyu öğretmenin ve işin sınırsız imkânlarını hissettirmenin zevki kadar iktidarını göstermenin gururuyla Mevlut’a bir bakış atardı. Hiçbir şey söylemeden esrarengiz bir havayla giderse kapıda bıraktıkları arkadaki Mevlut’a dönerlerdi. (KBT: 360) / Ferhat bi Mevludu uputio pogled koliko pun zadovoljstva što ga poučava i daje mu naslutiti beskrajne mogućnosti posla toliko i pun gordosti jer može demonstrirati svoju moć. Ako bi ostao tajnovit i ne bi ništa rekao, oni koje bi ostavio na vratima okretali su se Mevludu. (ČMMG: 428)

U primjerima (50), (51) i (52) pragmatička vrijednost šutnje jeste sakrivanje i tajnovitost likova. U primjeru (50) šutnjom se upućuje na sakrivanje likova koji su prethodno naručili bozu od uličnoga prodavača boze. U primjeru (51) šutnjom se ukazuje na tajnovitost likova koji su dolazili u kuću Šejh-efendije, gdje je i Mevlud nerijetko svraćao. U primjeru (52) Ferhatova šutnja označava njegovu tajnovitost u vezi s poslom u koji se on jako dobro razumije i u okviru kojega poznaje određene tajne koje se mogu spoznati samo iskustvom u navedenome poslu.

U primjeru (50) u originalnome tekstu šutnja tajnovitosti izražava se frazemom sessizliğe bürünmek, koji se povezuje s konceptom šutnje i 
koji je značenjski blizak bosanskome glagolu šutjeti / ušutjeti (https:// sozluk.gov.tr/: posjet: 9. 12. 2020). Stoga se u prijevodu i koristi glagol ušutjeti. Primjećuje se da se najveće razlike u originalnome tekstu i prijevodu na bosanski jezik uočavaju u okviru različitih tipova šutnje koji se u originalnome tekstu na turskome jeziku iskazuju frazemima [v. (1), (16), (21), (36), (37), (40), (49) i (50)]. Takve razlike ukazuju na činjenicu da se u prijevodu primjenjuje pristup u okviru kojega se komunikacijski kontekst povezuje s kognitivnim mehanizmima prijenosa informacija. $U$ takvim mehanizmima prijenosa informacija spoznaja i način razmišljanja pojedinaca usko su povezani s emocionalnim i kulturološkim karakteristikama zajednice u kojoj egzistiraju. Uzimajući u obzir činjenicu da kultura i kulturno naslijeđe utječu na spoznaju i način razmišljanja u međuljudskoj komunikaciji, frazemi mogu izazvati različite refleksije u različitim kulturama i jezicima (v. Baumann 2013: 7-8; Bukovčan 2016: 144-145). Stoga se najveće razlike i uočavaju u prijevodu konverzacijskih situacija u kojima se različiti tipovi šutnje izražavaju frazeološkim izrazima.

U primjeru (51) i u originalnome tekstu i u prijevodu šutnja tajnovitosti iskazuje se leksemom sessizlik (šutljivost, šutnja). U primjeru (52) $\mathrm{u}$ originalnome tekstu šutnja tajnovitosti označava se konverbom na -mAdAn, koji se dodaje na korijen glagola söylemek (govoriti; reći), dok se u prijevodu na bosanski jezik ovaj tip šutnje ispoljava odričnim oblikom glagola reći.

\section{Šutnja inteligentnosti i mudrosti}

U određenim kontekstualnim situacijama šutnja se može definirati kao simbol inteligentnosti i mudrosti. Stoga se takav tip šutnje može nazvati šutnjom inteligentnosti i mudrosti.

(53) Fatma daha akıllı, vakur ve sessizdi. (KBT: 342) / Fatma je bila inteligentnija, ozbiljnija i šutljivija. (ČMMG: 406)

U primjeru (53) šutnjom se označava inteligentnost i mudrost. Šutljivost Mevludove starije kćeri Fatme definira se kao njena inteligentnost i mudrost. I u originalnome tekstu i u prijevodu na bosanski jezik šutnja 
inteligentnosti i mudrosti izražava se leksemom sessiz (šutljiv). Kada se govori o navedenome tipu šutnje, treba spomenuti činjenicu da su jako rijetke konverzacijske situacije u kojima se uočavaju takvi i slični tipovi šutnje. Znatno se češće realiziraju konverzacijske situacije u kojima se bilježe tipovi šutnje koji nastaju kao rezultat određenih negativnih ili pak neizvjesnih i nekonvencionalnih situacija i iskustava.

\section{Običajna šutnja}

U određenim situacijama šutnja se realizira kao rezultat navika i običaja. Stoga se takva šutnja može nazvati običajnom šutnjom (v. Bulić 2018: 162).

(54) Hiçbir şey konuşmadan televizyona baktılar. Mevlut bu kendi halinde kadına herkesin haksızlık ettiğini düşündü. (KBT: 384) / U tišini su gledali televiziju. Pomislio je kako su se svi ogriješili o tu povučenu i mirnu ženu. (ČMMG: 458)

(55) Samihảnın yalanına inanıp inanmadığını anlayamadı. Bir süre sustular ve kalabalıklaşan muhallebicinin uğultusunu dinleyerek yemeklerini yediler. (KBT: 426) / Nije bio siguran je li Samiha povjerovala u tu laž. Jedno vrijeme su šutjeli i jeli slušajući žagor u prepunom restoranu. (ČMMG: 509)

(56) Televizyondaki haberlere bakarak (Cumhurbaşkanı bayram namazını İstanbul'da, Süleymaniye'de kılmıştı) hiç konuşmadan yemeklerini yiyorlardı. (KBT: 458) / Jeli su u tišini gledajući vijesti na televiziji (Predsjednik države klanjao je bajram-namaz u Istanbulu, u Sulejmaniji). (ČMMG: 550)

U primjerima (54), (55) i (56) uočava se da je šutnja prouzrokovana navikama i običajima. U romanu Kafamda Bir Tuhaflık običajna šutnja realizira se za vrijeme jela i za vrijeme gledanja televizije. U primjeru (54) običajna šutnja realizira se za vrijeme gledanja televizije, dok se u primjeru (55) šutnja nazire za vrijeme jela. U primjeru (56) običajna šutnja realizira se za vrijeme jela i gledanja televizije. U primjerima (54) i (56) u originalnome tekstu običajna šutnja iskazuje se konverbom na - $m A d A n$, koji se dodaje na korijen glagola konuşmak (pričati / 
ispričati; govoriti / izgovoriti), dok se u prijevodu upotrebljava sintagma u tišini. U primjeru (55) i u originalnome tekstu i u prijevodu običajna šutnja izražava se potvrdnim oblikom glagola susmak (šutjeti / ušutjeti; zašutjeti).

\section{Šutnja nerazumne osobe}

Šutnja nerazumne osobe jeste šutnja kojom se u određenim kontekstualnim situacijama odstupa od konvencionalnih komunikativnih pravila i postulata, a takva su odstupanja od uobičajenih postulata konverzacije prouzrokovana stanjem u kojem se govornik nalazi (v. Bulić 2018: 167).

(57) Mevlut içeri girince Samihảnın babasının koluna girip onu kapıya yürüttüğünü gördü. Son yıllarda iyice bunayan kayınpederi fazla konuşmuyor, iki kadeh rakıdan sonra uslu bir çocuk gibi kızlarının yanında sessizce oturuyordu. Mevlut onun köyden otobüse binip İstanbul'a nasıl gelebildiğine şaşıyordu. (KBT: 462) / Kada je ušao unutra, Mevlud je vidio kako Samiha, držeći ga ispod ruke, odvodi oca prema vratima. Njegov punac koji je posljednjih godina prilično posenilio nije mnogo pričao a nakon dvije čašice rakije sjedio bi uz svoje kćerke poput poslušnog djeteta. Mevlud se čudio kako je bio u stanju sjesti u autobus i sa sela doći u Istanbul. (ČMMG: 555)

U primjeru (57) može se primijetiti da Abdurahmanova konverzacija odstupa od uobičajenih postulata konverzacije. Isto tako, primjećuje se kako je odstupanje od uobičajenih postulata konverzacije prouzrokovano senilnošću, zbog čega se takva šutnja može nazvati šutnjom nerazumne osobe. Uočava se da se i u originalnome tekstu i u prijevodu na bosanski jezik šutnja nerazumne osobe izražava odričnim oblikom glagola konuşmak (pričati / ispričati; govoriti / izgovoriti).

\section{Zaključak}

U radu je analizirana pragmatička vrijednost različitih tipova šutnje koji su evidentirani u tekstu romana Kafamda Bir Tuhaflik autora Orhana Pamuka. Pored toga, kontrastivnom su se analizom uspoređivali različiti tipovi šutnje zabilježeni u originalnome tekstu romana 
s tipovima šutnje koji su predstavljeni u prijevodu na bosanski jezik. Analiza konkretnih kontekstualnih primjera ukazala je na činjenicu da šutnja predstavlja komunikativni resurs kojim se prenosi određeno značenje u realiziranim konverzacijama. U tekstu romana Kafamda Bir Tuhaflık zabilježeni su različiti tipovi šutnje kojima se prenose različita značenja u različitim kontekstualnim situacijama, a to su šutnja nesnalaženja [v. od (1) do (10)], dugotrajna i neprijatna šutnja [v. (11), (12) i (13)], šutnja poraza [v. (14)], šutnja protesta [v. od (15) do (20)], šutnja u nesreći [v. (21), (22), (23) i (24)], šutnja unutarnjeg previranja [v. (25), (26) i (27)], šutnja provjeravanja [v. (28)], šutnja o tabu temama [v. od (29) do (35)], šutnja odobravanja [v. (36), (37) i (38)], šutnja suzdržavanja [v. (39), (40), (41) i (42)], šutnja neznanja [v. (43)], zahtijevana šutnja [v. (44)], šutnja prihvatanja krivice [v. (45)], šutnja o posvjedočenome [v. (46)], šutnja položaja [v. (47), (48) i (49)], šutnja tajnovitosti [v. (50), (51) i (52)], šutnja inteligentnosti i mudrosti [v. (53)], običajna šutnja [v. (54), (55) i (56)] i šutnja nerazumne osobe [v. (57)]. Šutnja provjeravanja [v. (28)], šutnja prihvatanja krivice [v. (45)], šutnja tajnovitosti [v. (50), (51) i (52)] i šutnja inteligentnosti i mudrosti [v. (53)] jesu tipovi šutnje koji se realiziraju u konverzacijskim situacijama koje nisu oprimjerene u romanu Ponornica. Zapravo, to su tipovi šutnje koji nisu analizirani u studiji koja je korištena kao model na kojem se zasnivala naša analiza u teorijskome i metodološkome smislu. U analizi se moglo uočiti da se najčešće javljaju različiti tipovi šutnje koji nastaju kao rezultat određenih negativnih ili pak neizvjesnih i nekonvencionalnih situacija i iskustava. Mnogo su rjeđe konverzacijske situacije u kojima se uočavaju tipovi šutnje koji nastaju kao rezultat pozitivnih ili konvencionalnih situacija i iskustava.

$\mathrm{U}$ analizi se moglo vidjeti da se i u originalnome tekstu romana i u prijevodu na bosanski jezik različiti tipovi šutnje najčešće iskazuju potvrdnim oblikom glagola susmak (šutjeti / ušutjeti; zašutjeti) [v. (7), (9), (14), (28), (38), (42), (44), (46), (48) i (55)], odnosno odričnim oblikom glagola konuşmak (pričati / ispričati; govoriti / izgovoriti) [v. (6), (11), (12), (18), (29), (32) i (57)] i cevap vermek (odgovarati / odgovoriti) [v. (8), (15), (17), (26), (45) i (47)]. Zapravo, analiza je pokazala da se 
najveće sličnosti između originalnoga teksta i prijevoda bilježe u okviru različitih tipova šutnje koji se izražavaju potvrdnim oblikom glagola susmak (šutjeti / ušutjeti; zašutjeti) [v. (7), (9), (14), (28), (38), (42), (44), (46), (48) i (55)], odnosno odričnim oblikom glagola konuşmak (pričati / ispričati; govoriti / izgovoriti) [v. (6), (11), (12), (18), (29), (32) i (57)] i cevap vermek (odgovarati / odgovoriti) [v. (8), (15), (17), (26), (45) i (47)]. S druge strane, u analizi se moglo primijetiti da se najveće razlike u originalnome tekstu i prijevodu na bosanski jezik evidentiraju u okviru različitih tipova šutnje koji se u originalnome tekstu na turskome jeziku iskazuju frazemima [v. (1), (16), (21), (36), (37), (40), (49) i (50)]. $\mathrm{Na}$ temelju navedenoga može se zaključiti da je u prijevodu zastupljen multidisciplinarni pristup u kojem se komunikacijski kontekst povezuje s kognitivnim mehanizmima prijenosa informacija. Frazeološki izrazi mogu izazvati različite refleksije u različitim kulturama i jezicima, prvenstveno zato što emocionalne i kulturološke osobitosti zajednice $\mathrm{u}$ kojoj ljudi egzistiraju utječu na njihovu percepciju, spoznaju i način njihovoga razmišljanja. Stoga je i zabilježena najveća distinkcija prilikom prijevoda konverzacijskih situacija u kojima se različiti tipovi šutnje iskazuju frazemima.

Rezultati dobijeni u ovoj analizi trebali bi dati doprinos boljem spoznavanju i razumijevanju različitih tipova šutnje u različitim konverzacijskim situacijama. Pored toga, rezultati dobijeni u analizi mogu poslužiti kao dobar temelj i dobro polazište za daljnja istraživanja u vezi s različitim tipovima šutnje. Prije svega, mogu poslužiti kao dobar temelj i dobro polazište za istraživanje frazema koji se povezuju s konceptom šutnje u turskome i bosanskome jeziku. 


\section{Izvori}

ČMMG - Pamuk, Orhan (2015): Čudne misli u mojoj glavi (s turskoga prevele Sabina Bakšić i Alena Ćatović), Buybook, Sarajevo.

KBT - Pamuk, Orhan (2014): Kafamda Bir Tuhaflık, Yapı Kredi Yayınları, İstanbul.

\section{Literatura}

Aksoy, Ömer Asım (1989): Atasözleri ve Deyimler Sözlüğü 1-2, Beşinci Bask1, İnkılâp Kitapevi, İstanbul.

Bakšić, Sabina (2012): Strategije učtivosti u turskom jeziku, Filozofski fakultet u Sarajevu, Sarajevo.

Bakšić, Sabina; Bulić, Halid (2019): Pragmatika, Bookline, Sarajevo.

Baumann, Klaus-Dieter (2013): "The interdisciplinary concept of translational intertextuality, illustrated on the basis of LSP text networks", Synaps 29, 7-17.

Brown, Penelope; Levinson, Stephen C. (1987): Politeness: Some universals in language usage, 2. izdanje, Cambridge University Press, Cambridge.

Bukovčan, Dragica (2016): "Stručnojezična frazeologija i metaforika u međujezičnom i međukulturalnom kontrastiranju”, Fluminensia: časopis za filološka istraživanja 28/1, Odsjek za kroatistiku Filozofskoga fakulteta Sveučilišta u Rijeci, Rijeka, 143-162.

Bulić, Halid (2018): Pragmatički aspekti romana Ponornica Skendera Kulenovića, Institut za bosanski jezik i književnost u Tuzli, Tuzla.

Čaušević, Ekrem (1996): Gramatika suvremenoga turskog jezika, Hrvatska sveučilišna naklada, Zagreb.

Čaušević, Ekrem (2018): Ustroj, sintaksa i semantika infinitnih glagolskih oblika u turskom jeziku: turski i hrvatski jezik u usporedbi i kontrastiranju, Ibis grafika, Zagreb.

Đinđić, Marija (2014): Yeni Türkçe-Sırpça Sözlük, Türk Dil Kurumu Yayınları, Ankara.

Đinđić, Slavoljub; Teodosijević, Mirjana; Tanasković, Darko (1997): TürkçeSirpça Sözlük, Türk Dil Kurumu Yayınları, Ankara. 
Jahić, Dževad; Halilović, Senahid; Palić, Ismail (2000): Gramatika bosanskoga jezika, Dom štampe, Zenica.

Katnić-Bakaršić, Marina (2013): Stilistika dramskog diskursa, 2. izdanje, University Press, Sarajevo.

Kovačević, Barbara (2012): Hrvatski frazemi od glave do pete, Institut za hrvatski jezik i jezikoslovlje, Zagreb.

Levinson, Stephen C. (1983): Pragmatics, Cambridge University Press, Cambridge.

Stević, Slobodan (1997): Analiza konverzacije, Filološki fakultet Univerziteta u Beogradu, Beograd.

\section{Internetska stranica}

Türk Dil Kurumu Sözlükleri - Rječnici Turskoga jezikoslovnog društva, https://sozluk.gov.tr/. 


\title{
Pragmatic roles of different types of silence in Orhan Pamuk's novel Kafamda bir tuhaflik
}

\begin{abstract}
In certain conversational settings, silence does not only represent the absence of speech, but it is used as a means of communication conveying different meanings. The objective of this paper is to analyze the pragmatic role of silence in Orhan Pamuk's novel Kafamda Bir Tuhaflik. Examples of silence are registered in the original text of the novel Kafamda Bir Tuhaflik and contrastive analysis was used to compare them with the types of silence presented in the translations to Bosnian language. This was used to try to establish whether certain types of silence have an identical pragmatic value in Turkish and Bosnian language. The analysis compares syntactic structures expressing different types of silence in the original text of the novel and its translations to Bosnian language. Turkish language is the initial language of the analysis. Therefore, syntactic structures expressing different examples of silence in the original text of the novel are compared to the translational equivalents in Bosnian language. The analysis of specific contextual examples shows that the success of interpersonal communication depends to a great extent on accurate knowledge and understanding of different types of silence. The results obtained from the analysis contribute to better knowledge and understanding of different types of silence in different conversational settings and they can serve as a good basis and a good starting point for further research regarding different types of silence.
\end{abstract}

Key words: silence, pragmatic role, syntactic structures, Turkish language, Bosnian language

\section{Izjava autora o nepostojanju sukoba interesa i poštivanju općih etičkih kodeksa:}

Autor potvrđuje da ne postoji nikakav stvarni ili mogući sukob interesa vezan za ovaj tekst te da je tekst napisan u skladu s etičkim kodeksima prema preporukama COPE (Committee of Publishing Ethics). 